\title{
A study of medication errors during the prescription stage in the pediatric critical care services of a secondary-tertiary level public hospital
}

Lorena Michele Brennan-Bourdon ${ }^{1}$, Alan O. Vázquez-Alvarez², Jahaira Gallegos-Llamas³, Manuel Koninckx-Cañada ${ }^{4}$, José Luis Marco-Garbayo ${ }^{4}$ and Selene G. Huerta-Olvera ${ }^{5^{*}}$

\begin{abstract}
Background: Medication Errors (MEs) are considered the most common type of error in pediatric critical care services. Moreover, the ME rate in pediatric patients is up to three times higher than the rate for adults. Nevertheless, information in pediatric population is still limited, particularly in emergency/critical care practice. The purpose of this study was to describe and analyze MEs in the pediatric critical care services during the prescription stage in a Mexican secondary-tertiary level public hospital.

Methods: A cross-sectional study to detect MEs was performed in all pediatric critical care services [pediatric emergency care $(P E C)$, pediatric intensive care unit (PICU), neonatal intensive care unit (NICU), and neonatal intermediate care unit (NIMCU)] of a public teaching hospital. A pharmacist identified MEs by direct observation as the error detection method and MEs were classified according to the updated classification for medication errors by the Ruíz-Jarabo 2000 working group. Thereafter, these were subclassified in clinically relevant MEs.

Results: In 2347 prescriptions from 301 patients from all critical care services, a total of 1252 potential MEs (72\%) were identified, and of these 379 were considered as clinically relevant due to their potential harm. The area with the highest number of MEs was PICU $(n=867)$. The ME rate was $>50 \%$ in all pediatric critical care services and PICU had the highest ME/patient index (13.1). The most frequent MEs were use of abbreviations (50.9\%) and wrong speed rate of administration (11.4\%), and only $11.7 \%$ of the total drugs were considered as ideal medication orders.

Conclusion: Clinically relevant medication errors can range from mild skin reactions to severe conditions that place the patient's life at risk. The role of pharmacists through the detection and timely intervention during the prescription and other stages of the medication use process can improve drug safety in pediatric critical care services.
\end{abstract}

Keywords: Medication errors, Prescription error, Dispensing error, Pediatric emergency, Pediatric critical care

\footnotetext{
* Correspondence: selene.huerta@academicos.udg.mx

${ }^{5}$ Departamento de Ciencias Médicas y de la Vida. Centro Universitario de la

Ciénega. Universidad de Guadalajara, Guadalajara, Jalisco, Mexico

Full list of author information is available at the end of the article
}

(c) The Author(s). 2020 Open Access This article is licensed under a Creative Commons Attribution 4.0 International License, which permits use, sharing, adaptation, distribution and reproduction in any medium or format, as long as you give appropriate credit to the original author(s) and the source, provide a link to the Creative Commons licence, and indicate if changes were made. The images or other third party material in this article are included in the article's Creative Commons licence, unless indicated otherwise in a credit line to the material. If material is not included in the article's Creative Commons licence and your intended use is not permitted by statutory regulation or exceeds the permitted use, you will need to obtain permission directly from the copyright holder. To view a copy of this licence, visit http://creativecommons.org/licenses/by/4.0/ The Creative Commons Public Domain Dedication waiver (http://creativecommons.org/publicdomain/zero/1.0/) applies to the data made available in this article, unless otherwise stated in a credit line to the data. 


\section{Background}

Medication errors (MEs) are considered the single most preventable cause of patient injury derived from human factors [1]. MEs are defined by the National Coordination Council for Medication Error Reporting and Prevention (NCC MERP) as "any preventable event that may cause or lead to inappropriate medication use or patient harm while the medication is in the control of the health care professional, patient, or consumer" [2]. These can occur in the following stages of the medication use process: prescribing, transcribing, dispensing, administration, or monitoring [3]. Evidence shows that MEs occur most frequently during the prescription and administration stages [48]. A higher incidence of MEs has also been reported in emergency and intensive care services [9-12]. Children, including neonates and premature infants treated in these settings, are more prone to MEs because of high-stake situations that pertain to critically ill children, particularly weight-based dosing miscalculations and timely administration of medications [13, 14]. Moreover, the medication error rate in children has been reported up to three times higher than in adult patients [15].

Nevertheless, while the incidence and classification of MEs has been well studied in adult hospitalized patients $[4,7,10-12]$, clear information in pediatric population is scarce. In Latin American hospitals, including Mexico, most hospitals are public and have an increased demand for healthcare services, however, the active participation of pharmacists involved in patient care is very restricted $[16,17]$.

To the best of our knowledge, studies focused on MEs in pediatric patients admitted to the emergency and critical care units within Mexican public hospitals are limited. Therefore, the objective of this study was to describe MEs during the prescription stage in the pediatric critical care services of a Mexican secondarytertiary level public hospital.

\section{Methods}

\section{Study design}

A cross-sectional study was performed in a secondarytertiary public teaching hospital in western Mexico from March 2017 to November 2018 in the following pediatric critical care services: pediatric emergency care (PEC), neonatal intensive care unit (NICU), neonatal intermediate care unit (NIMCU), and pediatric intensive care unit (PICU). The study was approved by the Hospital's Bioethics and Research Committees.

\section{Detection system and analysis of MEs}

The inclusion criteria were patients in the age range from newborns to 6 months for NICU and NIMCU, and for PEC and PICU, from 1 month to 18 years of age with at least one prescribed medication order during their hospital stay.

The classification of MEs was based on the updated version by the Ruíz-Jarabo working group [18]. During the evaluation period in the different critical care areas, a member of the research team (J.G.L.) collected and analyzed the medication orders from each critical care service using the direct observation technique to detect MEs $[19,20]$. In this study, all medication orders [handwritten (legible or illegible), digital, or combined] include all prescribed drugs and are issued by attending physicians. A single medication order was analyzed per patient and each listed drug within the medication order was considered an individual prescription (drug name, dose, route of administration, speed rate of administration, and frequency of administration). Those patients without MEs in their medication orders were considered as "ideal medication orders". Handwritten medication orders are the norm and prescriptions that include abbreviations or the brand name of the drug instead of the active ingredient were considered outside the norm, and thus, classified as medication errors. Internationally recognized abbreviations were excluded. All detected MEs during the prescription stage were classified according to the medication error taxonomy defined by the Ruíz-Jarabo working group. Subsequently, MEs were analyzed to identify only those clinically relevant due to their potential for patient harm. These variables included wrong speed of administration, misinterpretation/mistaken drug units, and abbreviations for concentrated electrolytes and anticonvulsants. Abbreviations for saline and glucose/dextrose solutions were not considered.

The characteristics of MEs described in this study include number of orders, number of prescriptions, number of prescriptions per order $(\mathrm{P} / \mathrm{O})$, type of medication orders, number of illegible medication orders, and amendments. The following variables were evaluated: total number of potential medication errors and clinically relevant medication errors, prescription error rate ([total number of incorrect prescriptions/number of prescribed drugs] $\times 100$ ), ME/patient index (number of identified medication errors/total number of patients), type of medication error, percentage of patients with ideal medication orders, and prescription with ideal drugs.

The estimated number of medication orders for the four selected areas was previously established by a sample size calculation. The sample size of 301 hospitalized pediatric patients was determined by the formula described by Mendelhall et al. [21] considering the number of admissions in each critical care service and the average of MEs from previous studies [22-24]. 


\section{Statistical analysis}

Quantitative data were expressed as absolute frequencies, percentages and ratios. Analysis were performed using IBM SPSS Statistics for Windows, version 21.0 (Chicago, ILL).

\section{Results}

A total of 301 patients were evaluated in the pediatric critical care services under consideration. The total number of prescription drugs was 2347 with an average of 7.8 prescriptions per order; the highest being in the PICU (15.3 prescriptions per order). The general characteristics of the analyzed medication orders are shown in Table 1.

Among the 2347 prescriptions, a total of 1252 potential MEs (53.3\%) and 379 clinically relevant MEs (16.1\%) were identified. The pediatric services with the highest number of MEs were PICU (190) followed by PEC (139). Likewise, the PICU and the PEC had the highest clinically relevant prescription error rate (18.8 and $19.4 \%$ clinically relevant errors per prescription, respectively) and $\mathrm{ME} /$ patient index (1.6 and 2.9 clinically relevant errors per patient, respectively). The main findings are described in Table 2.

The potential clinical implications of MEs found in the critical care services including the mild or severe implications of the prescribed drugs are described in Table 3.

\section{Discussion}

Medication errors occur frequently in pediatric critical care settings affecting patient safety and quality of healthcare [15, 26, 27]. According to our knowledge, this is the first study reporting pediatric MEs in emergency and intensive care services in Mexico. The higher frequency of MEs could be attributed to the fact that the study was conducted in a teaching hospital with limited full-time human resources and the lack of an electronic system for medication orders. On the other hand, the percentage of MEs in other countries, such as the USA [28] and Spain [29] have reported lower values ranging from 5 to $10 \%$. This low frequency could reflect their rigorous health systems with electronic medical record use, as well as hospital pharmacy services, which are directly involved in the improvement of the medication process. Our study reports an occurrence and frequency of MEs that may also occur in other hospitals in Latin America, highlighting that improvements are still needed in pediatric critical care services.

Initially, 1252 MEs were detected representing 53.3\%, however, after a thorough analysis, only clinically relevant MEs (379) that could cause harm to the patient were considered and this percentage was reduced to $16.1 \%$. To obtain this percentage, abbreviations of glucose $5 \%$ and saline solution $0.9 \%$ (GS5\%, SSO.9\%, or SS, respectively) were discarded and only those abbreviations related to concentrated electrolytes and anticonvulsants, and the infusion rates or incorrect units of the registered drugs, were considered. These MEs are clinically relevant because according to the literature and clinical practice, patients with these errors are susceptible to mild skin reactions, such as phlebitis, rash, pain at the administration site and major complications that include cardiac rhythm disturbances, respiratory system reactions, and hypervolemia, among others [30].

The PICU and PEC areas had the highest number of MEs. This finding could be attributed, the high-stake and stressful situations that arise in these units, such as in resuscitations, where physicians must make immediate decisions in order to secure the well-being of the patients [31].

One study performed in the pediatric intensive care unit of a Spanish hospital found that 59\% of all MEs were caused by some illegible element compared with $25 \%$ of our results for the same pediatric service [32]. Nevertheless, abbreviations were also the leading cause of MEs in our study (68.5\%), however, only $13.1 \%$ were considered clinically relevant.

It is important to highlight that even though our study shows a high frequency of medication errors, most specialized hospitals in Mexico are teaching hospitals, which

Table 1 Characteristics of medication orders in the pediatric critical care services

\begin{tabular}{|c|c|c|c|c|c|c|c|c|c|c|}
\hline \multirow{2}{*}{$\begin{array}{l}\text { Pediatric } \\
\text { Service }\end{array}$} & \multirow{2}{*}{$\begin{array}{l}\text { Orders, } \\
\text { n }\end{array}$} & \multirow{2}{*}{$\begin{array}{l}\text { Prescriptions } \\
\text { (drugs), } \mathrm{n}\end{array}$} & \multirow{2}{*}{$\begin{array}{l}\text { Prescriptions/ } \\
\text { order }(\mathrm{P} / \mathrm{O})\end{array}$} & \multicolumn{3}{|c|}{ Type of medication order, n (\%) } & \multirow{2}{*}{$\begin{array}{l}\text { Illegible } \\
\text { medication } \\
\text { orders }^{\mathrm{a}}, \mathrm{n} \\
(\%)\end{array}$} & \multicolumn{3}{|c|}{ Amendments, n (\%) } \\
\hline & & & & Hand-written & Digital & Combined $^{\mathbf{b}}$ & & Total & Legible & Illegible \\
\hline PEC & 88 & 715 & 8.1 & 0 & 27 & 61 & $7(7.9)$ & $8(9.1)$ & 7 & 1 \\
\hline $\mathrm{PICU}$ & 66 & 1013 & 15.3 & 0 & 17 & 49 & $8(12.1)$ & $12(17.6)$ & 11 & 1 \\
\hline $\mathrm{NICU}$ & 68 & 332 & 4.9 & 0 & 35 & 33 & $7(10.2)$ & $12(17.6)$ & 11 & 1 \\
\hline NIMCU & 79 & 287 & 3.6 & 1 & 49 & 29 & $3(3.8)$ & $3(3.8)$ & 3 & 0 \\
\hline TOTAL & 301 & 2347 & 7.8 & $1(0.4)$ & $128(42.5)$ & $172(57.1)$ & $25(8.3)$ & $35(11.6)$ & 32 & 3 \\
\hline
\end{tabular}

D Drug, I Indication, NICU Neonatal Intensive Care Unit, NIMCU Neonatal Intermediate Care Unit, PEC Pediatric Emergency Care, PICU Pediatric Intensive Care Unit,

a Illegible medication orders would require a clarification from the attending physician to follow the therapeutic indication

${ }^{\mathrm{b}}$ Combined medication orders (handwritten + digital) 
Table 2 Characteristics of MEs in the pediatric critical care services according to the updated classification by the Ruíz-Jarabo 2000 working group

\begin{tabular}{|c|c|c|c|c|c|c|}
\hline \multirow[t]{3}{*}{ Variables } & \multicolumn{4}{|c|}{ Hospital pediatric critical care services } & & \\
\hline & \multirow[t]{2}{*}{ PEC } & \multirow[t]{2}{*}{ PICU } & \multirow[t]{2}{*}{$\mathrm{NICU}$} & \multirow[t]{2}{*}{ NIMCU } & \multicolumn{2}{|l|}{ Total } \\
\hline & & & & & $\mathrm{n}$ & $\%$ \\
\hline Total potential medication errors, n (\%) & $358(50.1)$ & $643(63.5)$ & $141(42.5)$ & $110(38.3)$ & 1252 & 53.3 \\
\hline Total clinically relevant medication errors ${ }^{\mathrm{b}}, \mathrm{n}$ & 139 & 190 & 31 & 19 & 379 & 30.3 \\
\hline Clinically relevant Prescription Error Rate ${ }^{\mathrm{b}} \%$ & 19.4 & 18.8 & 9.3 & 6.6 & 16.1 & \\
\hline Clinically relevant ME/patient Index & 1.6 & 2.9 & 0.5 & 0.2 & - & \\
\hline \multicolumn{7}{|l|}{ Types of Medication Errors ${ }^{\mathrm{a}}, \mathrm{n}(\%)$} \\
\hline -Wrong speed rate of administration ${ }^{\mathrm{b}}$ & 45 & 102 & 31 & 14 & 192 & 15.3 \\
\hline -Abbreviations & 258 & 432 & 85 & 83 & 858 & 68.5 \\
\hline Clinically relevant ${ }^{b}$ & 65 & 42 & 0 & 5 & 112 & 13.1 \\
\hline Not clinically relevant & 193 & 390 & 85 & 78 & 746 & 86.9 \\
\hline -Spelling error & 26 & 63 & 25 & 13 & 127 & 10.1 \\
\hline -Misinterpretation/mistaken drug units ${ }^{\mathrm{b}}$ & 29 & 46 & 0 & 0 & 75 & 6.0 \\
\hline Patients with ideal medication orders, n (\%) & $6(6.8)$ & $0(0.0)$ & $12(17.6)$ & $26(32.9)$ & 44 & 14.6 \\
\hline Prescriptions with ideal drugs, $\mathrm{n}(\%)$ & $17(2.4)$ & $146(14.4)$ & $45(13.5)$ & $66(23.0)$ & 274 & 11.7 \\
\hline
\end{tabular}

ME Medication Error, NICU Neonatal Intensive Care Unit, NIMCU Neonatal Intermediate Special Care Unit, PEC Pediatric Emergency Care, PICU Pediatric Intensive Care Unit

${ }^{a}$ According to the Institute for Safe Medication Practices (ISMP) Spain (12); ${ }^{\mathrm{b}}$ The clinically relevant abbreviations were KCL (Potassium Chloride) and PHT (Phenytoin)

represents a greater probability of finding MEs, particularly in critical care services. Furthermore, when comparing our results with other studies performed in Mexico, three studies stand out, one by Villegas F [33] where the percentage of MEs was $8.9 \%$; however, this study was conducted in a private and certified hospital, requiring specialized trained pharmacists. Another study performed in a public teaching hospital by del ReyPineda E. et al., reported a prescription error rate of $1.7 \%$ [34], which is very similar to PEC, and higher in two of the studied services (NICU and NIMCU). In the PICU however, the prescription error rate was almost twice as high compared to our results. Lastly, a review of prospective studies on medication prescription errors in Mexico conducted by Núñez-Sánchez A. et al., found an ME rate between 1.5 to 34\% [35]. These findings demonstrate the wide variability of prescription rates in private vs public Mexican hospitals. In other countries with similar healthcare conditions to Latin America, one Brazilian study found a ME rate of $7.4 \%$ and Colombian study found a ME rate of $97.3 \%$ [36] with a follow-up publication estimating that $67.2 \%$ of these errors reach the patient $[37,38]$.

The importance of this study demonstrates the need to include trained pharmacists to the healthcare team in Mexican public hospitals; to validate prescriptions, to provide prescription training to health care providers, and most importantly, to enhance drug safety. Literature has demonstrated that clinical pharmacists in intensive care units play a key role in the prevention of MEs and adverse drug events [39]. Furthermore, the impact that a clinical pharmacist has on improving patient safety has also been reported in a tertiary level teaching hospital [40], where clinical pharmacists are an integral part of the medical staff, and most importantly, the specialized pediatric pharmacist is considered the best fit for the 24-h critical care needed.

In neonatal or premature critical care areas, the main ME was related to the speed of administration, similar to other reports $[13,14]$. Also, a frequent ME was the use of abbreviations that could cause a misinterpretation of the medication order or a delay in the administration. It should be noted that patients in these areas are usually in critical states and neonates or premature infants do not have the ability to verbally express pain or physical discomfort, which could imply an overmedication when treating these symptoms. In addition, it has been reported that neonates are particularly vulnerable to the consequences of MEs as they are smaller in size and fragile, generally with immature organ systems. Therefore, the timely detection and prevention of MEs in neonates is particularly important given that neonates and premature infants are at high risk for error [9, 41, 42], with even minor errors possibly leading to short and longterm norm [26].

Of all the critical care areas evaluated, NIMCU presented the highest percentage of ideal medications for the specific needs of each patient, while PICU obtained 
Table 3 Main drugs related to the most frequent medication errors in the pediatric critical care services (PCCS)

\begin{tabular}{|c|c|c|c|c|c|}
\hline \multirow[t]{2}{*}{ PCCS } & \multirow[t]{2}{*}{ Types of Medication Errors } & \multirow[t]{2}{*}{ n (\%) } & \multirow[t]{2}{*}{ Drug related in MEs, $n$} & \multicolumn{2}{|c|}{ Clinical Relevance or Possible clinical implication ${ }^{*}$} \\
\hline & & & & Mild & Severe \\
\hline \multirow[t]{11}{*}{ PEC } & \multirow[t]{5}{*}{$\begin{array}{l}\text { Wrong speed rate of } \\
\text { administration }\end{array}$} & \multirow[t]{5}{*}{$\begin{array}{l}45 \\
(11.7)\end{array}$} & Omeprazole, 40 & $\begin{array}{l}\text { Abdominal pain, } \\
\text { Nausea }\end{array}$ & Respiratory system reactions \\
\hline & & & Ampicillin, 2 & $\begin{array}{l}\text { Phlebitis, Injection site } \\
\text { pain }\end{array}$ & $\begin{array}{l}\text { Morbilliform rash or Serious allergic } \\
\text { reactions }\end{array}$ \\
\hline & & & Metoclopramide, 1 & Diarrhea & Acute dystonic reaction \\
\hline & & & Amikacin, 1 & Injection site pain & Hearing loss \\
\hline & & & Ceftriaxone, 1 & Rash, Injection site pain & Hematological disorders \\
\hline & \multirow[t]{5}{*}{ Abbreviations } & \multirow{5}{*}{$\begin{array}{l}258 \\
(67.2)\end{array}$} & Glucose solution, 98 & Phlebitis & Hyperosmolar syndrome \\
\hline & & & Potassium chloride, 53 & $\begin{array}{l}\text { Injection site pain, } \\
\text { Phlebitis }\end{array}$ & Cardiac arrhythmias \\
\hline & & & Saline solution, 28 & Phlebitis & Hypervolemia \\
\hline & & & Phenytoin, 12 & Injection site pain, Rash & Cardiac rhythm disturbances \\
\hline & & & Others, 67 & & \\
\hline & Total No. of MEs & 384 & & & \\
\hline \multirow[t]{16}{*}{ PICU } & \multirow[t]{2}{*}{$\begin{array}{l}\text { Wrong speed rate of } \\
\text { administration }\end{array}$} & \multirow[t]{2}{*}{$\begin{array}{l}102 \\
(15.8)\end{array}$} & Omeprazole, 59 & $\begin{array}{l}\text { Abdominal pain, } \\
\text { Nausea }\end{array}$ & Respiratory system reactions \\
\hline & & & Metoclopramide, 43 & Diarrhea & Acute dystonic reaction \\
\hline & \multirow[t]{4}{*}{ Spelling error } & \multirow[t]{4}{*}{$63(9.8)$} & Fentanyl, 38 & $\begin{array}{l}\text { Headache, Nausea, } \\
\text { Vomiting }\end{array}$ & Loss of consciousness \& Tachycardia \\
\hline & & & Sufentanil, 15 & $\begin{array}{l}\text { Headache, Nausea, } \\
\text { Vomiting }\end{array}$ & Loss of consciousness \& Tachycardia \\
\hline & & & Furosemide, 8 & Electrolyte disorder & Cardiac rhythm disturbances \\
\hline & & & Others, 2 & & \\
\hline & \multirow[t]{4}{*}{$\begin{array}{l}\text { Misinterpretation/mistaken } \\
\text { drug units }\end{array}$} & \multirow[t]{4}{*}{$46(7.2)$} & Nystatin, 17 & $\begin{array}{l}\text { Oral irritation, } \\
\text { Sensitization }\end{array}$ & Stevens-Johnson syndrome \\
\hline & & & Albuterol, 15 & Throat irritation, Nausea & Cardiac rhythm disturbances \\
\hline & & & $\begin{array}{l}\text { Ipratropium bromide / } \\
\text { Albuterol, } 12\end{array}$ & Throat irritation, Nausea & Cardiac rhythm disturbances \\
\hline & & & Epinephrine, 2 & Dizziness, Sweating & Cardiac rhythm disturbances \\
\hline & \multirow[t]{5}{*}{ Abbreviations } & \multirow{5}{*}{$\begin{array}{l}432 \\
(67.2)\end{array}$} & Glucose solution, 174 & Phlebitis & Hyperosmolar syndrome \\
\hline & & & Potassium chloride, 25 & $\begin{array}{l}\text { Injection site pain, } \\
\text { Phlebitis }\end{array}$ & Cardiac arrhythmias \\
\hline & & & Saline solution, 66 & Phlebitis & Hypervolemia \\
\hline & & & Phenytoin, 17 & Injection site pain, Rash & Cardiac rhythm disturbances \\
\hline & & & Others, 150 & & \\
\hline & Total of ME & 643 & & & \\
\hline \multirow[t]{9}{*}{ NICU } & \multirow[t]{2}{*}{$\begin{array}{l}\text { Wrong speed rate of } \\
\text { administration }\end{array}$} & \multirow[t]{2}{*}{$31(22)$} & Omeprazole, 30 & $\begin{array}{l}\text { Abdominal pain, } \\
\text { Nausea }\end{array}$ & Respiratory system reactions \\
\hline & & & Metoclopramide, 1 & Diarrhea, Hypotension & Acute dystonic reaction \\
\hline & \multirow[t]{3}{*}{ Spelling error } & \multirow[t]{3}{*}{$\begin{array}{l}25 \\
(17.7)\end{array}$} & Fentanyl, 21 & $\begin{array}{l}\text { Headache, Nausea, } \\
\text { Vomiting }\end{array}$ & Loss of consciousness \& Tachycardia \\
\hline & & & Furosemide, 2 & Electrolyte disorder & Cardiac rhythm disturbances \\
\hline & & & Others, 2 & & \\
\hline & \multirow[t]{4}{*}{ Abbreviations } & \multirow{4}{*}{$\begin{array}{l}85 \\
(60.3)\end{array}$} & Glucose solution, 55 & Phlebitis & Hyperosmolar syndrome \\
\hline & & & Saline solution, 9 & Phlebitis & Hypervolemia \\
\hline & & & Multivitamin, 4 & Stomach discomfort & Hypervitaminosis \\
\hline & & & Others, 17 & & \\
\hline
\end{tabular}


Table 3 Main drugs related to the most frequent medication errors in the pediatric critical care services (PCCS) (Continued)

\begin{tabular}{|c|c|c|c|c|c|}
\hline \multirow[t]{2}{*}{ PCCS } & \multirow[t]{2}{*}{ Types of Medication Errors } & \multirow[t]{2}{*}{ n (\%) } & \multirow[t]{2}{*}{ Drug related in MEs, $n$} & \multicolumn{2}{|c|}{ Clinical Relevance or Possible clinical implication ${ }^{*}$} \\
\hline & & & & Mild & Severe \\
\hline & Total No. of MEs & 141 & & & \\
\hline \multirow[t]{12}{*}{ NIMCU } & \multirow[t]{3}{*}{$\begin{array}{l}\text { Wrong speed rate of } \\
\text { administration }\end{array}$} & \multirow[t]{3}{*}{$\begin{array}{l}14 \\
(12.7)\end{array}$} & Omeprazole, 12 & $\begin{array}{l}\text { Abdominal pain, } \\
\text { Nausea }\end{array}$ & Respiratory system reactions \\
\hline & & & Vancomycin, 1 & Nausea & Hypokalemia \& Red man Syndrome \\
\hline & & & Amikacin, 1 & Injection site pain & Hearing loss \\
\hline & \multirow[t]{3}{*}{ Spelling error } & \multirow[t]{3}{*}{$\begin{array}{l}13 \\
(11.8)\end{array}$} & Fentanyl, 6 & $\begin{array}{l}\text { Headache, Nausea, } \\
\text { Vomiting }\end{array}$ & Loss of consciousness \& Tachycardia \\
\hline & & & Furosemide, 3 & Electrolyte disorder & Cardiac rhythm disturbances \\
\hline & & & Others, 4 & & \\
\hline & \multirow[t]{5}{*}{ Abbreviations } & \multirow{5}{*}{$\begin{array}{l}83 \\
(75.5)\end{array}$} & Glucose solution, 37 & Phlebitis & Hyperosmolar syndrome \\
\hline & & & Potassium chloride, 5 & $\begin{array}{l}\text { Injection site pain, } \\
\text { Phlebitis }\end{array}$ & Cardiac arrhythmias \\
\hline & & & Saline solution, 9 & Phlebitis & Hypervolemia \\
\hline & & & Multivitamin, 4 & Stomach discomfort & Hypervitaminosis \\
\hline & & & Others, 28 & & \\
\hline & Total No. of MEs & 110 & & & \\
\hline
\end{tabular}

*The clinical implications were consulted at https://www.drugs.com/sfx/ [25]

HPMC Hydroxypropyl methylcellulose, ME Medication Error, NICU Neonatal Intensive Care Unit, NIMCU Neonatal Intermediate Special Care Unit, PCCS Pediatric critical care services, PEC Pediatric Emergency Care, PICU Pediatric Intensive Care Unit

the lowest percentage. This may be because the PICU service had a P/O numerically higher than NIMCU $[15.3$ vs. 3.6]. This $\mathrm{P} / \mathrm{O}$ value means that $\mathrm{PICU}$ patients have a greater quantity of prescribed drugs (polypharmacy) compared to NIMCU patients, and therefore, an increased risk of MEs, drug interactions and adverse drug reactions. One way to confirm this risk was through the clinically relevant $\mathrm{ME} /$ patient index, where a higher index was observed in PICU compared to NIMCU (2.9 vs. 0.2), which is consistent with a higher number of MEs. These findings could reflect similar working environments for each pediatric critical care service in Mexican or in other Latin American teaching hospitals.

Limitations of this study include its cross-sectional design since it was not possible to determine the real consequences of MEs detected in these patients. Also, only the prescription phase was evaluated in this study and not the rest of the medication use process, such as the dispensation and administration stages, or subclassifications (prescribed PRN vs scheduled or resuscitation situations), and disease severity in patients. Lastly, the direct observation method was time-consuming [27] since the pharmacist needed to attend each service to perform this task, limiting even further the number of detected MEs. Nonetheless, this study exposes the need to improve the quality of the prescription process in pediatric critical care patients, and in this regard, a longterm multicentric study is suggested.

Several proposals to mitigate MEs would be the creation of prescription programs and constant training for healthcare professionals, the implementation of pharmaceutical care to validate medication orders (prescribed doses, routes and interactions, among others.

\section{Conclusion}

Medication errors were frequent in all pediatric critical care services during the prescription stage due to the complex and stressful nature of the critical care setting. The need to establish reporting systems for the prevention of MEs through the participation of a pharmacist can significantly reduce their incidence due to an early and timely detection and thus, improve patient safety for the pediatric population in critical care services.

The findings from this study provide the framework for future longitudinal studies that include the intervention of pharmacists to minimize MEs, not only in the prescription stage, but in the other stages of the medication use process before they can reach or cause harm to patients.

\section{Abbreviations}

ME: Medication errors; NICU: Neonatal Intensive Care Unit; NIMCU: Neonatal Intermediate Care Unit; PICU: Pediatric Intensive Care Unit; PEC: Pediatric Emergency Care; NCC MERP: Coordinating Council for Medication Error Reporting and Prevention; P/O: Prescription/order

\section{Acknowledgements}

Not applicable.

\section{Authors' contributions}

BL: conception, data analysis and interpretation, drafted manuscript, final approval; VA: design, data analysis and interpretation, drafted manuscript, final approval; GJ: design, data acquisition and interpretation, final approval; 
KM: conception, data acquisition and interpretation, critical review, final approval; MJ: conception, data acquisition and interpretation, critical review, final approval; HS: conception and design, data acquisition, analysis and interpretation, drafted manuscript, critical review, final approval.

\section{Funding}

The total economic resources used for this research were provided by the Teacher Improvement Program (PROMEP), under the registration number PROMEP/103.5/12/3418 and by the corresponding author.

\section{Availability of data and materials}

The datasets generated during and/or analyzed during the current study are not publicly available due to previous confidentiality agreements with the Hospital's Ethics and Research Committees but are available from the corresponding author on reasonable request.

\section{Ethics approval and consent to participate}

This study was classified as "no risk", so only verbal consent was required from the parent or legal guardian of the child in order to participate in the study. Approval for the study and the collection of verbal consent to participate were obtained from the Research and Ethics Committees, with the registration number: 1225-12.

\section{Consent for publication}

Not applicable.

\section{Competing interests}

The authors declare that they have no competing interests.

\begin{abstract}
Author details
${ }^{1}$ Comisión para la Protección contra Riesgos Sanitarios del Estado de Jalisco (COPRISJAL), Guadalajara, Jalisco, Mexico. ${ }^{2}$ Instituto de Terapéutica Experimental y Clínica (INTEC). Departamento de Fisiología. Centro Universitario de Ciencias de la Salud, Universidad de Guadalajara, Guadalajara, Jalisco, Mexico. ${ }^{3}$ Egresada de la Licenciatura en Químico Fármaco Biólogo, Centro Universitario de la Ciénega, Universidad de Guadalajara, Guadalajara, Jalisco, Mexico. ${ }^{4}$ Servicio de Farmacia, Hospital Francesc de Borja, Gandía, Valencia, Spain. ${ }^{5}$ Departamento de Ciencias Médicas y de la Vida. Centro Universitario de la Ciénega. Universidad de Guadalajara, Guadalajara, Jalisco, Mexico.
\end{abstract}

Received: 24 April 2020 Accepted: 23 November 2020

Published online: 05 December 2020

\section{References}

1. Williams DJP. Medication Errors. R Coll Phys Edinb. 2007:37:343-6.

2. About medication errors. National Coordinating Council for Medication Error Reporting and Prevention (NCCMERP). 2020. https://www.nccmerp. org/about-medication-errors. Accessed 9 Aug 2020

3. World Health Organization. Medication Errors: Technical Series on Safer Primary Care. Geneva: World Health Organization; 2016. Licence: CC BY-NCSA $3.01 \mathrm{GO}$.

4. Tissot $\mathrm{E}$, Cornette $\mathrm{C}$, Demoly $\mathrm{P}$, et al. Medication errors at the administration stage in an intensive care unit. Intensive Care Med. 1999;25:353-9.

5. Storti M, Zucchi A, Buccoliero P. Risk analysis in the process of administering drugs in the emergency departments care: a multicenter observational study. Prof Inferm. 2011;64:213-8.

6. Ehsani SR, Cheraghi MA, Nejati A, et al. Medication errors of nurses in the emergency department. J Med Ethics Hist Med. 2013;6:11.

7. Ridley SA, Booth SA, Thompson CM. Prescription errors in UK critical care units. Anaesthesia. 2004;59:1193-200.

8. Zavaleta M, Castro LI, Reyes I, et al. Prescription errors in a primary care university unit: urgency of pharmaceutical care. Rev Bras Cienc Farm. 2008; 44:115-25.

9. Garrouste M, Philippart F, Bruel C, et al. Overview of medical errors and adverse events. Ann Intensive Care. 2012;2:2

10. Merino P, Álvarez J, Cruz Martín M, et al. Adverse events in Spanish intensive care units: the SYREC study. Int J Qual Health Care. 2012;24:10513.
11. Tomás S, Chanovas M, Roqueta F, et al. EVADUR: eventos adversos ligados a la asistencia en los servicios de urgencias de hospitales españoles. Emergencias. 2010;22:415-28.

12. Alhawassi TM, Krass I, Bajorek BV, et al. A systematic review of the prevalence and risk factors for adverse drug reactions in the elderly in the acute care setting. Clin Interv Aging. 2014;9:2079-86.

13. Chappell K, Newman C. Potential tenfold drug overdoses on a neonatal unit. Arch Dis Child Fetal Neonatal Ed. 2004;89:F483-4

14. Rishoej RM, Almarsdóttir AB, Christesen HT, et al. Identifying and assessing potential harm of medication errors and potentially unsafe medication practices in paediatric hospital settings: a field study. Ther Adv Drug Saf. 2018;9(9):509-22.

15. Kaushal R, Bates DW, Landrigan C, et al. Medication errors and adverse drug events in pediatric inpatients. JAMA. 2001;285(16):2114-20.

16. Alvarez-Risco A, Del-Aguila-Arcentales S. Pharmaceutical care in Latin America. In: The pharmacist guide to implementing pharmaceutical care. Cham: Springer; 2019. p. 183-90.

17. Haack SL, Mazar I, Carter EM, et al. Cultural sensitivity and global pharmacy engagement in Latin America: Argentina, Brazil, Ecuador, Guatemala, and Mexico. Am J Pharm Educ. 2019;83(4):7218.

18. Otero MJ, Castaño B, Martín R, et al. Updated classification for medication errors by the Ruiz-Jarabo 2000 group. Farm Hosp. 2008;32(1):38-52.

19. Montesi G, Lechi A. Prevention of medication errors: detection and audit. $\mathrm{Br}$ J Clin Pharmacol. 2009;67(6):651-5.

20. Manias E. Detection of medication-related problems in hospital practice: a review. Br J Clin Pharmacol. 2013;76(1):7-20.

21. Mendenhall W, Ott L, Scheaffer RL. Elementary survey sampling. Belmont: Duxbury Press; 1971. p. 39-48.

22. Aseeri MA. The impact of a pediatric antibiotic standard dosing table on dosing errors. Pediatr Pharmacol Ther. 2013;18(3):220-6.

23. Lavalle VA, Payro CTJ, Martínez CKA, et al. El error médico en la prescripción de medicamentos y el impacto de una intervención educativa. Bol Med Hosp Infant Mex. 2007;64(2):83-90.

24. Gutiérrez S, Mogni A, Berón A, et al. Errores de medicación en niños hospitalizados. Arch Pediatr Urug. 2011;82(3):133-40.

25. Drugs.com. Drug side effects from Drugs.com; c2000-2020 [Updated: 01 October 2020, Cited: 22 October 2020]. Available from: https://www.drugs. $\mathrm{com} / \mathrm{sfx} /$.

26. Raju TNK, Suresh G, Higgins RD. Patient safety in the context of neonatal intensive care: research and educational opportunities. Pediatr Res. 2011;70: 109-15.

27. Rishoej RM, Hallas J, Kjeldsen LJ, et al. Likelihood of reporting medication errors in hospitalized children: a survey of nurses and physicians. Ther Adv Drug Saf. 2018;9(3):179-92.

28. Anderson JG, Abrahamson K. Your health care may kill you: medical errors. Stud Health Technol Inform. 2017;234:13-7.

29. Sánchez ADLM, Medication M. Errors in a Spanish community pharmacy: nature, frequency and potential causes. Int J Clin Pharm. 2013;35(2):185-9. https://doi.org/10.1007/s11096-012-9741-0.

30. Wilmer A, Louie K, Dodek P, Wong H, Ayas N. Incidence of medication errors and adverse drug events in the ICU: a systematic review. Qual Saf Health Care. 2010;19(5):e7.

31. Moreira ME, Hernandez C, Stevens AD, et al. Color-coded prefilled medication syringes decrease time to delivery and dosing error in simulated emergency department pediatric resuscitations. Ann Emerg Med. 2015;66: 97-106.

32. Martínez AA, Sanchez IJ, Casanueva L. Impact of an intervention to reduce prescribing errors in a pediatric intensive care unit. Intensive Care Med. 2012;38:1532-8

33. Villegas F, Figueroa-Montero D, Barbero-Becerra V, Juárez-Hernández E, Uribe M, Chávez-Tapia N, González-Chon O. La importancia de la farmacovigilancia intrahospitalaria en la detección oportuna de los errores de medicación. Gac Med Mex. 2018;154(2):172-9.

34. Del Rey-Pineda E, Estrada-Hernández LO. Errores de medicación en pacientes del Hospital Regional Lic. Adolfo López Mateos del ISSSTE. Med Int Méx. 2014;30:641-50.

35. Núñez Sánchez A, Cornejo Bravo JM, Pérez Morales MA. Evaluación de estudios prospectivos sobre errores de medicación en la prescripción: revisión sistemática. Rev Mex Ciencias Farmacéuticas. 2014;45(1):07-14.

36. de Bortoli Cassiani SH, Monzani S, Aparecida A, Bauer de Camargo Silva AE, Trevisani Fakih F, Perufo Opitz S, Cardoso T. Identificación y análisis de los 
errores de medicación en seis hospitales brasileños. Ciencia y Enfermería. 2010;16(1):85-95

37. Machado-Alba JE, Ossa-Ochoa LM, Lotero-Jaramillo N, Valencia-Rojas A. Identificación de errores de medicación en un hospital de primer nivel de Pereira, Colombia. Rev Fac Med. 2013;61(3):267-73.

38. Machado-Alba JE, Moncada JC, Moreno-Gutiérrez PA. Medication errors in outpatient care in Colombia, 2005-2013. Biomédica. 2016;36(2):251-7.

39. Tripathi S, Crabtree HM, Fryer KR, et al. Impact of clinical pharmacist on the pediatric intensive care practice: an 11-year tertiary center experience. J Pediatr Pharmacol Ther. 2015;20(4):290-8.

40. Cunningham KJ. Analysis of clinical interventions and the impact of pediatric pharmacists on medication error prevention in a teaching hospital. J Pediatr Pharmacol Ther. 2012;17:365-73.

41. Rinke $M L$, Bundy DG, Velasquez CA, et al. Interventions to reduce pediatric medication errors: a systematic review. Pediatrics. 2014;134(2):338-60.

42. Ghaleb MA, Barber N, Franklin BD, Wong IC. The incidence and nature of prescribing and medication administration errors in pediatric inpatients. Arch Dis Child. 2010;95:113-8.

\section{Publisher's Note}

Springer Nature remains neutral with regard to jurisdictional claims in published maps and institutional affiliations.

Ready to submit your research? Choose BMC and benefit from:

- fast, convenient online submission

- thorough peer review by experienced researchers in your field

- rapid publication on acceptance

- support for research data, including large and complex data types

- gold Open Access which fosters wider collaboration and increased citations

- maximum visibility for your research: over $100 \mathrm{M}$ website views per year

At $\mathrm{BMC}$, research is always in progress.

Learn more biomedcentral.com/submissions 